\title{
Tuberculosis Control: Patient Perception Regarding Orientation for the Community and Community Participation ${ }^{1}$
}

\author{
Márcio Curto ${ }^{2}$ \\ Lúcia Marina Scatena ${ }^{3}$ \\ Rubia Laine de Paula Andrade 4 \\ Pedro Fredemir Palha ${ }^{5}$ \\ Elisângela Gisele de Assis ${ }^{6}$ \\ Beatriz Estuque Scatolin ${ }^{7}$ \\ Tereza Cristina Scatena Villa ${ }^{8}$
}

To evaluate, from the patient's perspective, actions of orientation for the community and community participation carried out in tuberculosis control in health services in Ribeirão Preto - SP. This was an evaluative quantitative exploratory study which used part of the Primary Care Assessment Tool, adapted and validated for tuberculosis care, applied through interview, with 100 patients. Indicators of the instrument and analysis of variance were used. The realization of social partnerships for delivery of the sputum pot together with the community, the delivery of the sputum pot to the community by professionals, and the participation of the community to discuss the problem of tuberculosis were identified, 5\%, $6 \%$ and 5\%, respectively. The health services with fewer patients in treatment showed the best indicators. The actions of social partnerships, searching for respiratory symptomatics in the community and community participation in tuberculosis control are poorly incorporated by health services.

Descriptors: Tuberculosis; Consumer Participation; Community-Institutional Relations; Health Evaluation.

\footnotetext{
1 Paper extrated from Master's Thesis "Atenção individual, enfoque familiar e orientação à comunidade nas ações de controle da tuberculose na percepção de diferentes atores", presented to Escola de Enfermagem de Ribeirão Preto, Universidade de São Paulo, WHO Collaborating Centre for Nursing Research Development, SP, Brazil. Supported by FAPESP, process \#2007/02648-7 and CNPq/ MS-SCTIE-DECIT 25/2006 process \#410547/2006-9.

2 RN, M.Sc. in Nursing. E-mail: marciocurto@usp.br.

3 Professor, Universidade Federal do Triângulo Mineiro, MG, Brazil. E-mail: Imscatena@uol.com.br.

${ }^{4}$ RN, Doctoral Student, Programa Interunidades de Doutoramento em Enfermagem, Escola de Enfermagem da Universidade de São Paulo e Escola de Enfermagem de Ribeirão Preto da Universidade de São Paulo, SP, Brazil. E-mail: rubia@eerp.usp.br.

${ }^{5}$ RN, Ph.D. in Nursing, Associate Professor, Escola de Enfermagem de Ribeirão Preto, Universidade de São Paulo, WHO Collaborating Centre for Nursing Research Development, SP, Brazil. E-mail: palha@eerp.usp.br.

${ }^{6}$ RN, M.Sc. in Nursing, Escola de Enfermagem de Ribeirão Preto, Universidade de São Paulo, WHO Collaborating Centre for Nursing Research Development, SP, Brazil. E-mail: elisasis@eerp.usp.br.

7 RN. E-mail: scatolin@eerp.usp.br.

${ }^{8}$ RN, Ph.D. in Nursing, Full Professor, Escola de Enfermagem de Ribeirão Preto, Universidade de São Paulo, WHO Collaborating Centre for Nursing Research Development, SP, Brazil. E-mail: tite@eerp.usp.br.
} 


\title{
Controle da tuberculose: percepção dos doentes sobre orientação a comunidade e participação comunitária
}

O objetivo deste estudo foi avaliar, sob a percepção dos doentes, ações de orientação para a comunidade e participação comunitária, realizadas no controle da tuberculose em serviços de saúde de Ribeirão Preto, SP. É pesquisa avaliativa quantitativa exploratória que utilizou parte do Primary Care Assessment Tool, adaptado e validado para atenção à tuberculose, aplicado por meio de entrevista a 100 doentes. Utilizaram-se indicadores do instrumento e análise de variância. Foram identificadas a realização de parcerias sociais para entrega do pote para coleta de escarro junto à comunidade, entrega do pote para coleta de escarro na comunidade pelos profissionais e a participação da comunidade para discutir o problema da tuberculose, 5, 6 e 5\% respectivamente. Os serviços de saúde com menor número de doentes em tratamento apresentaram os melhores indicadores. Conclui-se que as ações de parcerias sociais, busca de sintomáticos respiratórios na comunidade e participação da comunidade no controle da tuberculose são pouco incorporadas pelos serviços de saúde.

Descritores: Tuberculose; Participação Comunitária; Relações Comunidade-Instituição; Avaliação em Saúde.

\section{Control de la tuberculosis: percepción de los enfermos sobre orientación a la comunidad y participación comunitaria}

\begin{abstract}
El objetivo de este estudio fue evaluar, bajo la perspectiva de los enfermos, las acciones de orientación para la comunidad y la participación comunitaria, realizadas en el control de la tuberculosis en servicios de salud de Ribeirao Preto, Sao Paulo. Se trata de una investigación de evaluación cuantitativa exploratoria que utilizó parte del Primary Care Assessment Tool, adaptado y validado para la atención a la tuberculosis, aplicado por medio de entrevista a 100 enfermos. Fueron utilizados indicadores del instrumento y el análisis de la variancia. Fueron identificadas: la realización de alianzas sociales para obtener el pote para recolección de esputo junto a la comunidad (5\%); la entrega del pote para recolección de esputo en la comunidad por los profesionales (6\%); y, la participación de la comunidad en la discusión del problema de la tuberculosis $(5 \%)$. Los servicios de salud con menor número de enfermos en tratamiento presentaron los mejores indicadores. Se concluye que las alianzas sociales, la búsqueda de sintomáticos respiratorios en la comunidad y, la participación de la comunidad en el control de la tuberculosis son poco incorporadas por los servicios de salud.
\end{abstract}

Descriptores: Tuberculosis; Participación Comunitaria; Relaciones Comunidad-Institución; Evaluación en Salud.

\section{Introduction}

Tuberculosis (TB) remains a serious public health problem. An untreated person with the active disease infects on average 10 to 15 people a year. Furthermore, every second a new infection by the tuberculosis bacteria takes place in the world and one third of the population is infected, with an increased risk of illness in individuals with compromised immune systems ${ }^{(1)}$. In Brazil, there is a clear shift in the political scenario of confronting this disease, in which the participation of civil society stands out(2).

The importance of communication and social participation has already been verified in the control of many health problems and this was also evident in TB control after its insertion in the Global Plan to Stop TB by the World Health Organization(3). Accordingly, the Ministry of Health highlights that healthcare 
professionals should mobilize the community to identify the "chronic coughers" in families, clubs, churches and closed communities (prisons, mental hospitals, shelters and nursing homes) and direct them to carry out sputum examinations ${ }^{(4)}$.

The idea to train and use community volunteers to carry out supervised treatment (ST) has been successful in some locations. A study performed in Ecuador showed the existence of groups that seek the motivation of newly diagnosed patients by cured patients as a means of encouraging therapeutic adherence ${ }^{(5)}$. The formation of support groups consisting of patients themselves and stimulated by health teams has been explored for some time in several countries with significant success ${ }^{(5-6)}$, diverging from the vision of authors who suggest the need for training of professionals to carry out directly observed treatment of short duration (DOTS) at home $^{(7)}$. It can be affirmed that in the current scenario of confrontation of TB in Brazil, the performance of the community sector is indisputable and indispensable. The participation of those who work directly with and/ or represent the populations affected by the problem cannot be dismissed ${ }^{(2)}$.

This article corroborates a series of studies on tuberculosis published in the last two years in this journal and it was identified that in this period, six articles and an editorial on the theme were published, the DOTS strategy being the focus of three original articles, an original article focused on the treatment of the disease, another on TB/HIV co-infection and a review of the literature addressing the control of communicators, which shows the paramount importance, for the comprehension of the dynamic of tuberculosis control, of studies that address the community's involvement in the disease control actions, as suggested by the present study(7-13).

In Ribeirao Preto, a city with a population of 547,417 inhabitants, its municipal health system is comprised of 14 hospitals, 31 primary health care units, five outpatient clinics of reference and the Family Health Units ( $22 \%$ coverage). The attention to TB is still centralized and carried out by specialized teams of the Tuberculosis Control Program which are located in five health districts (North, South, East, West and Central). The teams are fixed but not exclusive to the program, and are minimally composed of: one doctor, two nursing assistants and a registered nurse. In 2007, the city presented 189 TB cases, $77.7 \%$ coverage of ST. The cure rate that year was $68.5 \%$, abandonment $2.1 \%$, and death $1.4 \%{ }^{(14)}$.
This study aimed to evaluate, from the patients' perspective, actions of orientation for the community and community participation, performed in tuberculosis control carried out in health services in the city of Ribeirao Preto, São Paulo.

\section{Methods}

This was a quantitative, prospective survey conducted with 100 TB patients, interviewed from June to July 2007, that met the following inclusion criteria: being over 18 years of age, residing in Ribeirão Preto, being in treatment for at least a month, agreeing with the Terms of Free Prior Informed Consent and being out of the prison system.

A component instrument of the Primary Care Assessment Tool (PCAT), formulated and validated in Brazil(15) $^{(15)}$ adapted to evaluate tuberculosis care ${ }^{(16)}$ was used.

The instrument contains specific questions about each organizational component of the Primary Health Care. In this study, five specific variables were used to evaluate the community oriented actions of tuberculosis control.

Data were stored and analyzed using the Statistica 8.0 software. The response categories used for each question were: 1 = never, 2 = almost never, $3=$ sometimes, 4 = often and 5 = Always, following a Likert type scale.

Data analysis was performed in three steps: exploratory data analysis; construction of indicators and comparisons between the health units in relation to indicators of the dimension of orientation for the community. A significance of $5 \%$ for all statistical tests was adopted.

The categories of responses to the questions of the questionnaire were quantified by obtaining the relative frequency of each category, expressed as a percentage.

Each indicator was determined through the sum of the scores of the categories of patients' responses divided by the total number of patients to obtain a mean value.

To compare the Health Units with respect to each indicator of the community context, the data were subjected to the analysis of variance (ANOVA) with a criterion of classification, using the $F$ test. Analysis of variance was applied to the variables that comprised the indicators and satisfied the assumptions of independence, homoscedasticity and normality. The assumption of equal variance (homoscedasticity) required by the ANOVA was 
verified using the Levene's test ${ }^{(17)}$. For the indicators that showed differences between the Health Units the Tukey's test was performed with correction for samples of different sizes.

The research project was approved by the Research Ethics Board of the School of Nursing of Ribeirao Preto, University of São Paulo, Protocol n. 0762/2007, taking into account the recommendations of Resolution $\mathrm{n}^{\circ}$. $196 / 96$ of the National Health Council.

For ethical reasons the names of health units with TCPs involved in the study were omitted, assigning the letters $A, B, C$ and $D$ to designate these health care services, with unit E excluded from the study because TB patients were not being attending there in the period of data collection.

\section{Results}

Of the 100 patients interviewed, 39\% originated from unit $A, 24 \%$ from unit $B, 22 \%$ from unit $C$, and $15 \%$ from unit $D$.

The results of the mean values of the indicators and the $p$ value for the $F$ test of variance analysis for the dimension "orientation for the community" for the health unit, $A, B, C$ and $D$, are shown in Table 1.

Table 1 - Labels of variables and units with TCPs, the mean value of the indicators with a confidence interval, total mean value of the indicators and $\mathrm{p}$ value for $\mathrm{F}$ test of the dimension orientation for the community, according to patients, Ribeirão Preto, 2007

\begin{tabular}{lccccccc}
\hline \multicolumn{2}{l}{ Labels of the variables } & $\mathbf{A}$ & $\mathbf{B}$ & $\mathbf{C}$ & $\mathbf{D}$ & Total Mean & $\mathbf{P}$ \\
\hline V1 & Mean IC & $4.13[3.60 ; 4.66]$ & $4.33[3.74 ; 4.93]$ & $4.64[4.21 ; 5.06]$ & $4.13[3.27 ; 4.99]$ & 4.29 & 0.5848 \\
V2 & Mean IC & $4.23[3.75 ; 4.71]$ & $4.50[3.93 ; 5.07]$ & $3.45[2.67 ; 4.24]$ & $2.47[1.49 ; 3.44]$ & 3.86 & 0.0004 \\
V3 & Mean IC & $1.10[0.98 ; 1.23]$ & $1.00[1.00]$ & $1.18[0.80 ; 1.56]$ & $1.13[0.85 ; 1.42]$ & 1.10 & 0.6655 \\
V4 & Mean IC & $1.05[0.95 ; 1.15]$ & $1.00[1.00]$ & $1.14[0.93 ; 1.34]$ & $1.60[0.88 ; 2.32]$ & 1.14 & 0.0107 \\
V5 & Mean IC & $1.00[1.00]$ & $1.17[0.82 ; 1.51]$ & $1.32[0.90 ; 1.74]$ & $1.13[0.85 ; 1.42]$ & 1.13 & 0.2982 \\
\hline
\end{tabular}

Legend: IC - Interval with $95 \%$ confidence. $p$ - Level of significance.

V1 Questioning of patients and family members regarding the resolvability of problems by health professionals; V2 Observation of the realization of educative work by professionals to inform the community about TB; V3 Realization of social partnerships to deliver the sputum collection pot by the professionals V4 Observation of visits of the professionals to the neighborhood, to deliver the sputum pot; V5 Request, by the professionals, for the participation of someone from the community to discuss the problem of TB.

When asked about the concern of the health team with the resolution of services provided, $78 \%$ of the patients responded that they were always questioned. For the indicator covering campaigns and educative work carried out by health team, $66 \%$ of the patients responded that such activities were always being carried out. Regarding social partnerships for TB control, 95\% of the patients affirmed that they had never noted the existence of such activities. In relation to the indicator of performance of extra activities to control TB, $94 \%$ of patients responded that they never observed the team performing activities to control TB outside the unity. And finally, for the indicators of the dimension "orientation for the community" the patients were questioned about social participation in the local control of TB and $95 \%$ of patients affirmed that the team never solicits the involvement of community representatives to discuss the problems of TB.

The results showed that the indicators for "questioning of the patient and his family as to the resolvability of their health problems by professionals of the unit (V1)", "creation of social partnerships to deliver the sputum pot by the professionals (V3)" and "soliciting, by professionals, the participation of someone from the community to discuss the problem of TB (V5)" there were no statistically significant differences between the health units $A, B, C$ and $D$, which were considered similar with respect to these indicators with levels of significance $(p)=0.5848$ for $V 1,0.6655$ for $V 3$, and 0.2982 for $V 5$, therefore higher than $5 \%$.

The indicators: "informing the community about TB by health professionals (V2)" and "delivering sputum examination pots by professionals in the community (V4)" showed a statistically significant difference between the health units that provide care to TB patients ( $p=0.0004$ for V2 and $p=0.0107$ for V4). For these indicators Tukey's test was performed (Figures 1 and 2). 


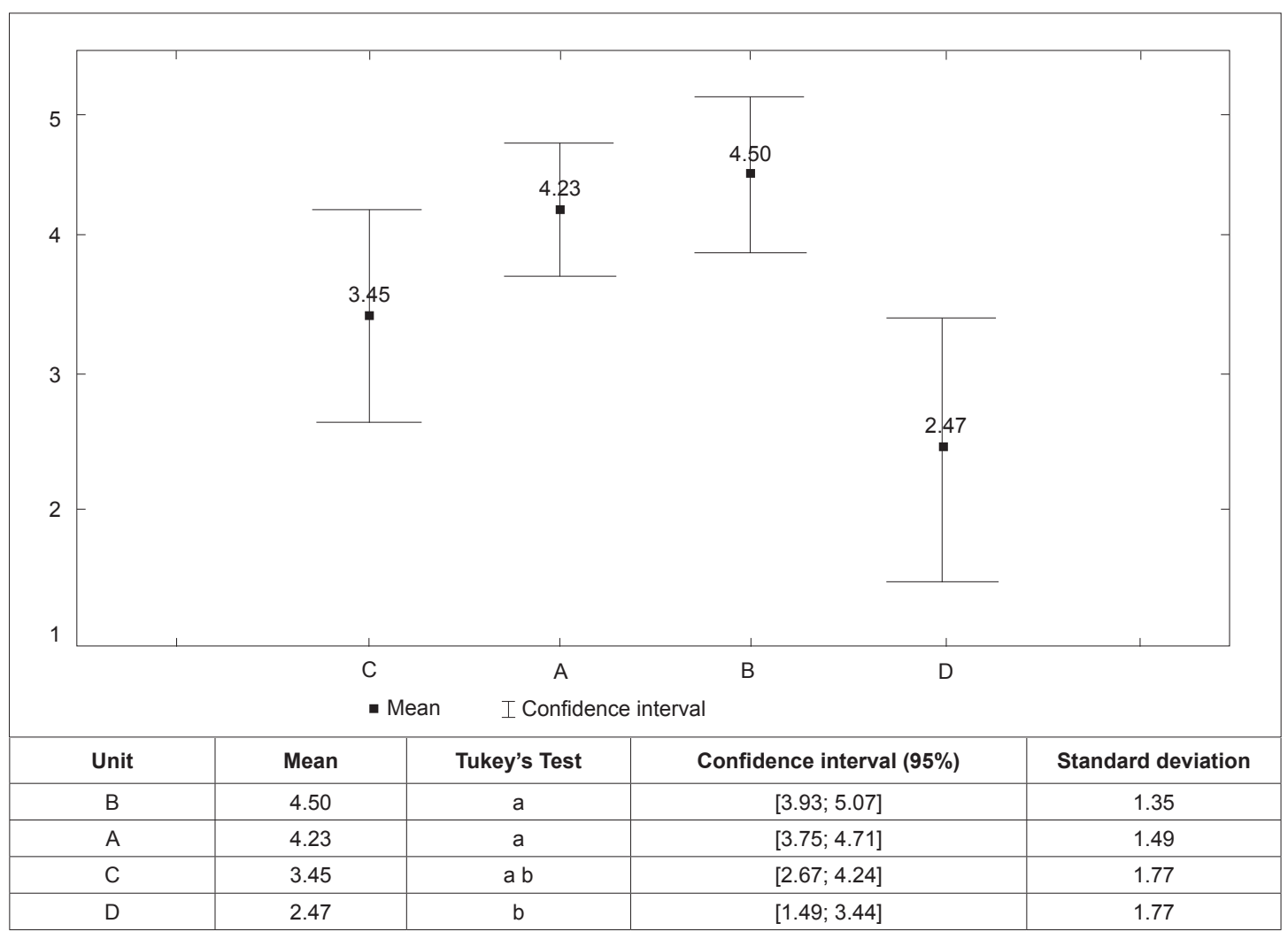

Figure 1 - Mean, confidence interval, standard deviation, and Tukey's test of the indicator: informing the community about TB by health professionals from the perception of patients, Ribeirão Preto, 2007

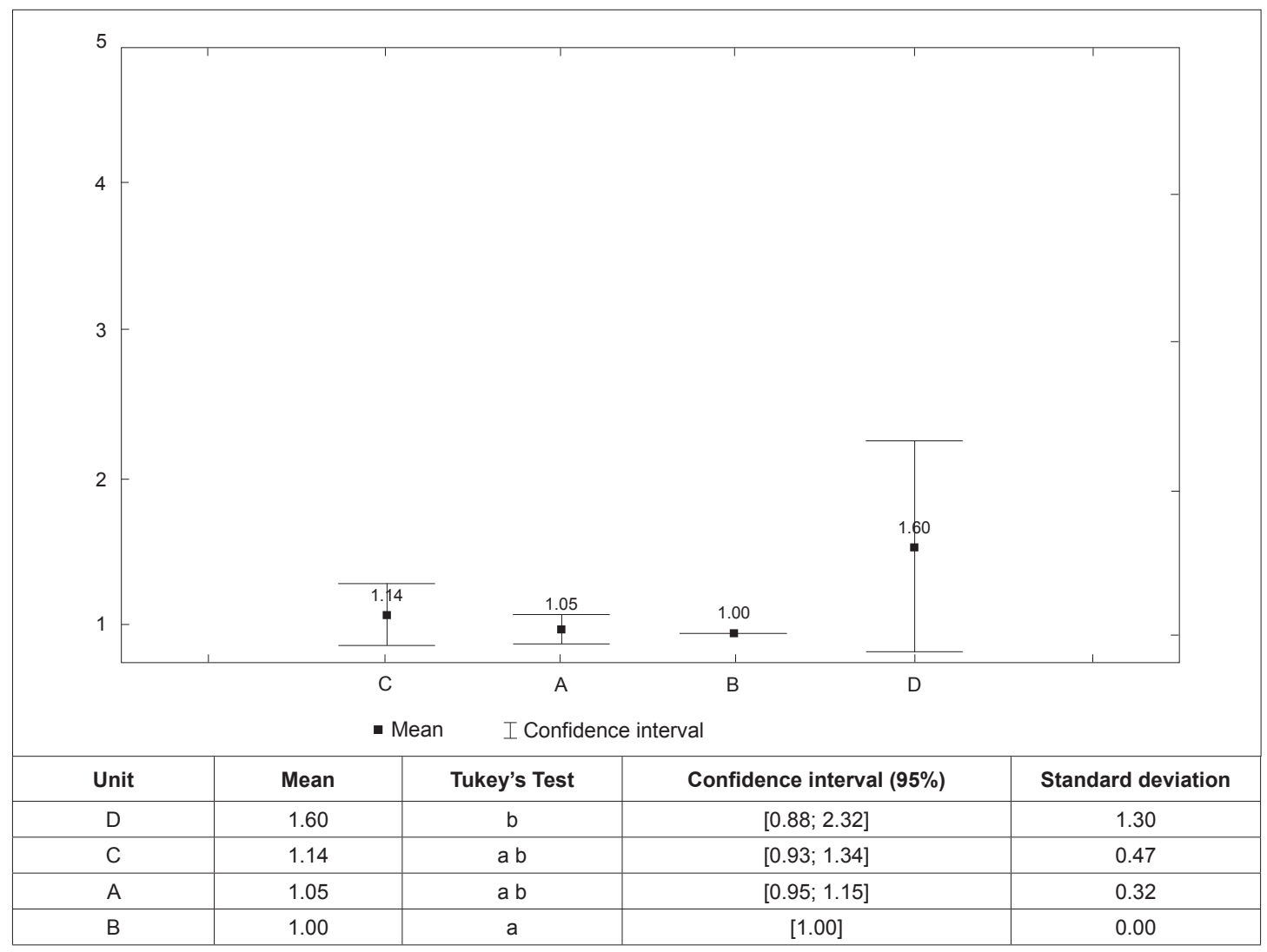

Figure 2 - Mean, confidence interval, standard deviation, and Tukey's test for the indicator: delivery of sputum examination pot by the professionals in the community from the perception of patients, Ribeirão Preto, 2007 
The Tukey's test (Figure 1), considered similar the means of units $A, B$ and $C$ and the means of the units $C$ and $D$, and although the mean of the units $A, B$ and $C$ show the better performance of these health services, unit $C$ could not be considered different from unit $D$ which showed the worst performance compared with other health units in relation to the indicator "informing the community about TB by health professionals".

Regarding the indicator "delivering sputum examination pots by professionals in the community", the Tukey's test (Figure 2) considered similar the means of units $A, B$ and $C$, as well as units $A, C$ and $D$, thus making evident a considerable difference only between units $B$ and $D$.

\section{Discussion}

When analyzing the realization of social partnerships for basic actions to control TB, such as the supply of the sputum collection pot, there is an absence of these actions by the health services in TB control. One study showed that most social interventions are being characterized as circumstantial and discontinuous, and that the first initiatives were taken and consolidated with the churches. In many Brazilian cities, the local health services, schools and social service agencies linked to churches, philanthropic entities and non-governmental organizations have been developing programs of monitoring and support for families in situations of special difficulty(18). Although that not being the reality of the health services involved in this study, the need is clear for investments by the public health sector in strengthening social partnerships with public institutions in a systematic way, encouraging and strengthening community action already existing in the city.

Regarding the indicator relating to soliciting community participation to discuss TB by professionals, it is worrying that $95 \%$ of patients reported that they had never observed such an occurrence, since $81 \%$ of respondents were in supervised treatment, therefore, in frequent contact with health professionals. There is a need to go beyond the current vision among local professionals and managers of social policies regarding the inability of the poor to care for themselves(19). Within this perspective, it becomes necessary to invest in innovative postures and practices and in the dissemination of alternative experiences which lead toward the autonomy and self-confidence of these

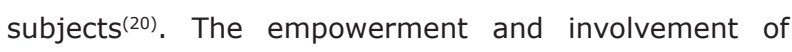
patients with TB against the disease is a growing area, but is not a new concept ${ }^{(21)}$.
The Ribeirao Preto municipality has a local TB committee that has sought to act in an dynamic way to maximize the performance of community health services seeking to change this negative characteristic evidenced by the low indicators of the actions of Seeking Respiratory Symptomatics (SRS) and qualification of care observed in this study.

Despite the increased commitment of the different levels of government to incorporate the practice of relating with community organizations, it is undeniable that there still exists some resistance on the part of government institutions in dealing with this notoriously critical actor. Moreover, the unsatisfactory performance shown in this study for the indicators of the dimension "orientation for the community", encounters support in the ideas that it should not be expected that the community response in TB control is generated spontaneously(2).

Another important factor to be highlighted concerns the domicile visit conducted by the team during the ST. Considering that $81 \%$ of patients interviewed were receiving this type of treatment, such visits could be better exploited to overcome the deficiencies highlighted by the indicators of the dimension "orientation for the community", since the health professional, from the evaluation of housing, family, socioeconomic, cultural and health conditions can develop an action plan to attend, in an integral way, the individual and their family and can establish a bond with the individual and the family, making them co-responsible for the care(22).

\section{Conclusion}

The results of this study showed that the development of actions in TB control by health professionals do not involve the community, in view of the relatively low means of the variables V3 $(1.10[0.85 ; 1.42])$, V4 $(1.60$ $[0.88 ; 2.32])$ and V5 $(1.13[0.85 ; 1.42])$ with their respective confidence intervals, and that the actions for health education are not yet part of the work of the teams. However, this is not a characteristic exclusive to the care of tuberculosis, but also to the entire health system, because, although it is still incipient, community participation in health care actions has become more evident.

In addition to the therapeutic resources that reduce the needs of patients in search of a cure, it has become necessary to sensitize health teams working in tuberculosis control services regarding the need for greater involvement and knowledge from these professionals related to the biopsychosocial needs of 
the patients. Health professionals should incorporate into the work process, actions for the sensitization and participation of the organized society and there is a need to internalize the necessity of user participation in discussions about local disease control, because it then becomes possible to evaluate not only the service provided but also to raise the health needs of the local population.

In the actions of TB control civil society does not only need to be informed about what the disease is and how it is transmitted, but also its co-responsibility in controlling the disease that grows and takes shape as a major public health problem in the country. However, it is noteworthy that even actions of professional responsibility, such as health education or orientation regarding the disease and its prevention have not been performed efficiently by the health teams, as evidenced by this study. Finally, the knowledge and the consequent resolution of health inequalities will only be translated into policy proposals, if this search for shared responsibility exists, which means that each social actor fulfills their part in the success of health interventions.

\section{References}

1. World Health Organization. Global tuberculosis control: surveillance, planning, financing: WHO report 2008. Geneva: WHO; 2008.

2. Santos-Filho ET, Gomes ZMS. Estratégias de controle da tuberculose no Brasil: articulação e participação da sociedade civil. Rev Saúde Pública. 2007; 41(Supl. 1):111-6.

3. Waisbord S. Beyond the medical-informational model: Recasting the role of communication in tuberculosis control. Soc Sci Med. 2007; 65(10):2130-4.

4. Ministério da Saúde (BR). Fundação Nacional da Saúde. Tuberculose: Guia de vigilância epidemiológica. Brasília: Ministério da Saúde / Fundação Nacional de Saúde; 2002.

5. Jaramillo E. Contribución de la comunidad a la atención de la tuberculosis: una perspectiva Latinoamericana. Contribution of the community to detection of tuberculosis: a Latin American contribution. Geneva: World Health Organization; 2002. WHO/ CDS/TB/2002.304(S)2002.

6. Akramul I. Community participation in TB control as part of social development: the experience of BRAC. Int J Tuberc Lung Dis. 2005; 9(11S1):31-7.

7. Cardozo Gonzales RI, Monroe AA, Arcêncio RA, Oliveira MF, Ruffino Netto A, Villa TCS. Indicadores de desempenho do DOT no domicílio para o controle da tuberculose em município de grande porte, SP, Brasil. Rev. Latino-Am. Enfermagem. 2008; 16(1):95-100.

8. Gazetta CE, Santos MLSG, Vendramini SHF, Poletti NAA, Pinto Neto JM, Villa TCS. Controle de comunicantes de tuberculose no Brasil: revisão de literatura (1984- 2004). Rev. Latino-Am. Enfermagem. 2008;16(2):306-13.

9. Villa TCS. Produção do conhecimento da enfermagem no controle da tuberculose no Brasil. Rev. Latino-Am. Enfermagem. 2008;16(4):655-6.

10. Terra MF, Bertolozzi MR. O tratamento diretamente supervisionado (DOTS) contribui para a adesão ao tratamento da tuberculose?. Rev Latino-am Enfermagem. 2008; 16(4):659-64.

11. Paz EPA, Sá AMM. Cotidiano do tratamento a pessoas doentes de tuberculose em unidades básicas de saúde: uma abordagem fenomenológica. Rev. Latino-Am. Enfermagem. 2009;17(2):180-6.
12. Santos MLSG, Ponce MAZ, Vendramini SHF, Villa TCS, Santos NSGM, Wysocki AD et al. A dimensão epidemiológica da coinfecção TB/HIV. Rev. Latino-Am. Enfermagem. 2009; 17(5):683-8.

13. Sanchez AIM, Bertolozzi MR. Além da DOTS (Directly Observed Treatment Short-Course) no controle da tuberculose: interface e compartilhamento de necessidades. Rev. Latino-Am. Enfermagem. 2009;17(5):689-94.

14. Secretaria Municipal da Saúde (RP). [internet]. Ribeirão Preto: Plano de Saúde 2005-2008; [Acesso em: 07 jul 2008]. Disponível em: http://www.ribeiraopreto.sp.gov.br/ ssaude/i16principal.asp?pagina=/ssaude/vigilancia/planeja / i16indplano.htm.

15. Almeida C, Macinko J. Validação de uma metodologia rápida das características organizacionais e do desempenho dos serviços de atenção básica do Sistema Único de Saúde (SUS) em nível local. Brasília: OPAS; 2006.

16. Villa TCS, Ruffino-Netto A. Questionário para avaliação de desempenho de serviços de atenção básica no controle da tuberculose no Brasil. J. bras. Pneumol. 2009; 35(6):610-2.

17. Vieira S. Análise de Variância. São Paulo: Atlas; 2006.

18. Vasconcelos EM. A priorização da família nas políticas de saúde. Saúde em Debate.1999; 23(53):6-19.

19. Neder G. Ajustando o foco das lentes: um novo olhar sobre a organização das famílias no Brasil. In: Kaloustian SM. Família Brasileira: A base de tudo. São Paulo (SP): Cortez; 1994. p. 26-46.

20. Takashima GK. O desafio da política de atendimento à família: dar vida as leis - uma questão de postura. 1994. In: Vasconcelos EM. A priorização da família nas políticas de saúde. Saúde em Debate. 1999; 23(53):6-19.

21. World Health Organization. Empowerment and involvement of tuberculosis patients in tuberculosis control: documented experiences and interventions. Stop TB Partnership. Geneva: WHO; 2007.

22. Ohara ECC, Ribeiro MP. Assistência Domiciliaria. In: Ohara ECC, Saito RXS. Saúde da família: considerações teóricas e aplicabilidade. São Paulo (SP): Livraria e Editora Martinari; 2008. p. 115-27. 